\title{
Manuscript
}

Click here to download Manuscript: PS Soussi et al 2015 Manuscript- PLSO-D-15-00792 R1.doc

Click here to view linked References

\section{Plant-associated microbiomes in arid lands: Diversity, ecology and biotechnological potential}

2

3 Asma Soussi ${ }^{1}$, Raoudha Ferjani ${ }^{2}$, Ramona Marasco ${ }^{1}$, Amel Guesmi ${ }^{2}$, Hanene Cherif ${ }^{2}$, Eleonora Rolli ${ }^{3}$, Francesca

4 Mapelli $^{3}$, Hadda Imene Ouzari ${ }^{2}$, Daniele Daffonchio ${ }^{1,3}$ and Ameur Cherif ${ }^{4 *}$

5

$6 \quad{ }^{1}$ Biological and Environmental Sciences and Engineering Division, King Abdullah University of Science and Technology, Thuwal 23955-6900,

7 Kingdom of Saudi Arabia.

$8{ }^{2}$ Laboratory of Microorganisms and Active Biomolecules, Faculty of Sciences of Tunis, University of Tunis El Manar, Campus Universitaire,

9 2092, Tunis, Tunisia

$10{ }^{3}$ Department of Food Environmental and Nutritional Sciences, Università degli Studi di Milano, 20133, Milano, Italy.

$11{ }^{4}$ University of Manouba, Higher Institute of Biotechnology, LR11-ES31 Biotechnology and Bio-Geo Resources Valorization, Biotechpole Sidi

12 Thabet, 2020, Ariana, Tunisia.

13

$14 *$ Correspondence to: cherif.ameur@gmail.com 


\section{Abstract}

18 Background Aridification is a worldwide serious threat directly affecting agriculture and crop production. In arid 19 and desert areas, it has been found that microbial diversity is huge, built of microorganisms able to cope with the environmental harsh conditions by developing adaptation strategies. Plants growing in arid lands or regions facing prolonged abiotic stresses such as water limitation and salt accumulation have also developed specific physiological and molecular stress responses allowing them to thrive under normally unfavorable conditions.

23 Scope Under such extreme selection pressures, special root-associated bacterial assemblages, endowed with capabilities of plant growth promotion (PGP) and extremophile traits, are selected by the plants. In this review, we provide a general overview on the microbial diversity in arid lands and deserts versus specific microbial assemblages associated with plants. The ecological drivers that shape this diversity, how plant-associated microbiomes are selected, and their biotechnological potential are discussed.

Conclusions Selection and recruitment of the plant associated bacterial assemblages is mediated by the combination of the bio-pedo-agroclimatic conditions and the plant species or varieties. Diversity and functional redundancy of these associated PGPR makes them very active in supporting plant improvement, health and resistance to drought, salt and related stresses. Implementing proper biotechnological applications of the arid and desert-adapted PGPR constitute the challenge to be raised.

34 Keywords: Plant associated microbiome, Arid land, Extreme environments, Drought, Salinity, Plant Growth Promoting Rhizobacteria, Sustainable agriculture, Biotechnology 


\section{Introduction}

Arid areas cover nearly $47 \%$ of Earth's land surface. Such extended regions are characterized by various harsh environmental conditions mainly soil deficiency in water and nutrients, high salinity and acidity, low precipitation, high temperatures and UV irradiation (Whitford 2002). All the organisms thriving in these extreme environmental conditions, including plants and bacteria, adopt complex survival strategies to alleviate abiotic stresses. In desert environments, microorganisms are the first colonizers (Mapelli et al. 2012; Borin et al. 2010). They possess special adaptation mechanisms, partly related to their ability of expressing and regulating only those genes required to survive and respond appropriately to the physical and chemical composition of these particular habitats (Bohnert et al. 1995; Begley et al. 2002; Boor 2006; Colica et al. 2014). They are able to create stable associations with higher organisms like fungi, lichens and mosses to form the so-called biological soil crusts (BSC) which have a crucial performance in stabilizing soil against erosion and in the restoration of deserts soils (de-Bashan et al. 2010; Bashan et al. 2012; Xu et al. 2013). BSCs can also be favourable niches for the germination of plant seeds. Microorganism colonization and services in extreme environments are essential for the plant establishment. While microorganisms favour the availability of water and nutrients for the plant, in return plant root system supply carbon sources for growth, representing a stable survival niche (Neilands 1995; Graham and Vance 2000; Richardson et al. 2009). In the plant root system, the rhizosphere, the first millimetres of soil surrounding plant root surface, is a thin dynamic layer of high activity and metabolism. Plant rhizosphere represents a suitable survival niche to microorganisms where nutrients are more available. In this compartment, bacteria are the most abundant microorganisms and since they are mostly providing useful services to support root and plant growth they are commonly defined as Plant Growth Promoting Rhizobacteria (PGPR). PGPR exert beneficial effects on the growth of the host plant via direct and indirect mechanisms. They directly promote the plant growth by increasing the availability of nutrients, for instance by fixing atmospheric nitrogen (Graham and Vance 2000; Richardson et al. 2009), solubilizing inorganic phosphate and producing siderophores that increase the availability of mineral nutrients such as iron (Neilands 1995; Richardson 2001). PGPR contribute to the modulation of plant hormone balance thought the synthesis of hormone-like molecules, mainly auxins, cytokinins and gibberellins (Costacurta and Vanderleyden 1995; Spaepen et al. 2007). Indirect mechanisms include the prevention of attacks of plant pathogens through the synthesis of antibiotics or antifungal compounds and through competition for nutrients (Van Loon et al. 
1997; McCully 2005; Couillerot et al. 2009; Saharan and Nehra 2011). On their side, plants noticeably contribute to the selection of PGPR by releasing root exudates, which generate a positive selection pressure and increase competitiveness among bacteria in root colonization (Shukla et al. 2013). A fraction of PGPR can also enter in root interior tissues, the so called endosphere, establishing the endophytic populations' community (Hallmann et al. 1997; Zinniel et al. 2002; Compant et al. 2005; Cankar et al. 2005; Danhorn and Fuqua 2007; Dias et al. 2009; Rhoden et al. 2015). Plants harbor endophytic bacteria that colonize a variety of internal plant tissues namely shoot, seeds and root tissues (Rosenblueth and Martínez-Romero 2006). In this context, Ulrich et al. (2008) identified Paenibacillus, Methylobacterium and Stenotrophomonas endophytes in the shoot tips and zygotic embryos of Norway pruce (Picea abies). In other studies, the endophytic bacteria Methylobacterium extorquens, Pseudomonas synxantha, mycobacterium sp. and Rhodotorula minuta were isolated from shoot tips of callus cultures of Scots pines (Pinus sylvestris L.) (Laukkanen et al. 2000, Pirttila et al. 2000). Beside, different bacterial genera have been identified within the endophytic community of potato (Solanum tuberosum) root tissues, for instance Rheinheimera, Dyadobacter, Devosia, Pedobacter and Pseudoxanthomonas (Manter et al. 2010). In Mammilaria fraileana seeds, endophytic bacteria distributed underneath the membrane covering the embryo and in the vascular tissue have been detected in addition to a large population of endophytic bacteria that have been isolated from stems and roots (Lopez et al. 2011). For instance, Bacillus megaterium, Pseudomonas putida and Enterobacter sakazakii have been isolated from the vascular cylinder, while Azotobacter vinelandii has been isolated from the root cortex.

This symbiotic association can be established without harming the plant (Lopez et al. 2011). Hence, several endophytes are of great importance given the beneficial effects that they offer to their host plants. Some endophytes are endowed with promoting growth potential (Dias et al. 2009; Bae et al. 2009; Lopez et al. 2011; Etesami et al. 2014) and biocontrol activities against phytopathogens (Melnick et al. 2013; Falcäo et al. 2014). These particular characteristics lead them to be employed in several biotechnological applications. Thanks to their secondary metabolites, endophytes are employed as medicinal remedies (Strobel 2007; Qin et al. 2011) and as a tool for phytoremediation of organic contaminants giving their ability to degrade xenobiotics (Lodewyckx et al. 2002; Kuiper et al. 2004; Germaine et al. 2006; Doty 2008). They also play an important role in soil fertility and improvement of sustainable production of non-food crops for biomass and biofuel production (Ryan et al. 2008). In stressful conditions mimicking arid and desert environments, it has been shown that biotic resistance of Quercus pubescens to insect pest infestation is not affected by warming and drought stresses. Leaf palatability is rather 
93

influenced by the variability of trichome density implicated in such induced adaptation (Backhaus et al. 2014). Similarly, in salt stressed plants, adaptation implies a complex regulation machinery involving Ethylene Responsive Factor (ERF) (Klay et al. 2014). There is an increasing body of literature showing that arid soils may favour the selection of bacteria capable of providing suitable services to alleviate plant drought stress (Marasco et al. 2012; Marasco et al. 2013a; Shelef et al. 2013) suggesting that this adaptation may be manifesting in the bacterial assemblages.

Another important factor affecting the functioning of the root systems in arid soils is the multiple symbiotic interactions such as those that may occur between different life domains. An interesting case is the mutualistic tripartite symbiotic interaction established between the desert plant Salsola inermis with the beetle Conorhynchus pistor and its symbiotic bacterium Klebsiella pneumonia (Shelef et al. 2013). The bacterial symbiont inhabiting the gut of the plant-hosted beetle larvae, provide nitrogen to the beetle and the plant hosts. On its side, the host plant protects the beetle from predators and parasites with its roots and provides organic matter to the animal and to its symbiont. This example shows that symbiotic cooperation is capable to improve the growth sustainability of the partners under the harsh conditions of the desert. In addition, plant genotype was shown to have a direct effect in shaping the rhizosphere associated microbial communities (Haney et al. 2015).

Plants surviving in arid ecosystems can sustain specific root associated PGPR communities that are selected by the environmental factors peculiar of the different locations (Marasco et al. 2013a; Ferjani et al. 2015; Mapelli et al. 2013). Plant and cultivar type as well as nutriments richness of the soil, are pivotal factors for PGPR recruitment (Zhang et al. 2014; Latour et al. 1996). This selection gives rise to diverse PGPR communities with common capabilities for improving plant functionalities under the harsh conditions determined by drought and saline stresses in arid environments.

Within this context, several studies have explored this unique root-soil interface and assessed its biodiversity in arid lands, with particular interest for i) understanding PGPR activities involved in plant growth promotion and protection, ii) assessing the importance of the PGPR ecological-niche and diversity, and iii) exploiting PGPR to improve agricultural sustainability. In the following sections we discuss these aspects in the light of the recent literature.

\section{Microbial diversity associated to plants growing in arid lands and deserts}


Arid regions are characterized by low rainfall and substantial unvegetated areas, which offer a typical ecosystem with patchwork-shaped microbial assemblages (Pointing and Belnap 2012; Nagy et al. 2005). In the recent years, several surveys have been focused on the complexity of the microbial diversity associated to soils in these extreme ecosystems. Despite the different geographic location of arid lands and deserts across the world, the bacterial communities of lithic substrates were dominated by Cyanobacteria (DiRuggiero et al. 2013). In addition, Proteobacteria, Firmicutes, Actinobacteria and Bacteriodetes are the main phyla generally detected in these soils. In the Taklamakan desert, the largest mobile desert in Asia (China), fifteen phyla were obtained but the most abundant were Proteobacteria (25.10\%), Firmicutes (24.8\%), Bacteriodetes (22.7\%) and Actinobacteria (8.9\%), respectively (An et al. 2013). In another Asian desert, the Gobi desert, 13 phyla were observed confirming the dominance of Firmicutes (69.9\%), Proteobacteria (12.2\%) and Bacteroidetes (8.2\%) (An et al. 2013).

The Sonoran and Mohave deserts in North America present BSCs bacterial communities dominated by Cyanobacteria and a few proportion of bacteria related to Acidobacteria, Actinobacteria, Bacteroidetes, Proteobacteria, Chloroflexi and Deinococcus phyla. The bacterial communities in the Atacama Desert, the oldest and driest desert located in South America, showed the dominance of Actinobacteria and Chloroflexi with a low abundance of Acidobacteria and Proteobacteria (Neilson et al. 2012). These data have been confirmed also by the characterization of the bacterial community in the Tataouine Desert, a part of the world largest Sahara Desert in South Tunisia (Chanal et al. 2006). The common diversity traits observed in the bacterial communities of different deserts may be attributed to the largely common harsh environmental conditions of all these deserts, which are however affected by microbial cell inputs determined by the circulation of the airborne dust associated to sand storms (Nagy et al. 2005).

Despite the presence of similar bacterial community in arid lands and deserts, plants are able to shape and select specific root-associated bacterial communities that include bacteria capable to cope with the abiotic stress of these ecosystems (Table 1, Figure 1).

Several studies confirmed that the so called rhizosphere effect holds as well in desert ecosystems. 16S rRNA gene sequences produced by PCR-DGGE analysis of the bacterial community associated with the roots of Larrea tridentate located in the Mohave Desert of southern California, revealed a predominance of Proteobacteria (Bradyrhizobiaceae, Rhodospirillaceae, Pseudomonadaceae, Aurantimonadaceae, Enterobacteriaceae, Xanthomonadaceae, and Alcaligenaceae), Bacteriodetes (Chitinophagaceae and Flexibacteraceae), Firmicutes 
(Bacillaceae), and Actinobacteria (Micrococcaceae) (Jorquera et al. 2012). In arid, yet cultivated soils in Egypt, the bacterial communities associated to the rhizosphere of pepper and medical plants plants were prevalently colonized by Firmicutes and Proteobacteria, while the bulk soil was characterized by the abundance of Actinobacteria and Firmicutes (Marasco et al. 2012; Koberl et al. 2011). In the same case study, Marasco et al. (2012) found different distribution of cultivable bacterial genera in different fractions of root system. Bacillus spp. (68\% of the isolates) were mainly isolated from the endosphere, while Klebsiella spp. were dominating the isolate collections from the rhizosphere and the root surrounding soil, representing $61 \%$ and $44 \%$ of the isolates, respectively (Marasco et al. 2012). Ferjani et al. (2015) observed in date palms from South Tunisian oases a rhizosphere community completely different from that in the root surrounding soil, supporting the consideration that date palm root exudates are strongly shaping the bacterial community. A rhizosphere effect was also observed in the halophyte Salicornia sp. sampled from the Chotts and Sebkha saline systems in the South of Tunisia (Mapelli et al. 2013).

All these studies proved that arid environments select very diverse bacterial communities that are shaped by the resources made available by the plant roots (Figure 1).

\section{Ecological drivers selecting the plant-associated microbiome}

Over the past decade, many research works have been focused on the plant associated microbiome selection. Progress in molecular tools has increased our understanding of the composition, the function and the ecological drivers of plant associated microbial assemblages. Despite the various microenvironments of the plant, including the phyllosphere, carposphere and endosphere, the rhizosphere has been the most investigated. A particular attention has been addressed to explore the PGPR diversity in this compartment in relation to different ecological drivers. The rhizosphere is defined as the soil fraction adhering to root plant strongly influenced by root exudates. It is well documented that the composition of root exudates depends on plant type, growth stage and environmental conditions (Duineveld et al. 1998; Gabriele et al. 2001; Appuhn and Joergensen 2006; Van Overbeek and Van Elsas 2008; Cavaglieri and Etcheverry 2009). Further studies showed how the composition of root exudates determines the recruitment of plant-associated bacteria. It has been shown that root exudates have a significant role in shaping the abundance of rhizosphere bacterial communities in herbaceous and arboreal plants (Zhang et al. 2014). Besides, it has been recently demonstrated that plant genotypic variations can also influence the rhizosphere associated microbiome (Haney et al. 2015). Interestingly, it has been shown in the same work that accessions of Arabidopsis 
thaliana inhibited specifically some Pseudomonadacea species, namely P. brassicacearum, P. fluorescens and $P$. syringae, without affecting most of the microbiome. Hence, plant genotype is a crucial factor in determining plant associated bacteria that influence the plant health and physiology according to specific biotic and abiotic stresses. Furthermore, it has been proved that Olea europaea L. genotype has a more relevant impact on endophytic communities in olive leaves compared to the soil type, the environmental conditions and the geographic location (Müller et al. 2015). This study has been performed on 10 Olea europaea L. cultivars leaves sampled from olive trees growing at a single agricultural site in Spain and from nine wild olive trees developing in natural habitats in Greece, Cyprus and on Madeira Island. A strong correlation between bacteria endophytic composition and plant genotypes has been highlighted.

In addition to the selection operated by plants, abiotic stresses are the selective forces contributing to shape the bacterial community associated to roots (Figure 2). A complex interaction between environmental and abiotic factors was shown to play an important role in shaping bacterial diversity, as well as to affect the properties of soils. It has been demonstrated that the biological state of agricultural soils and land use history play an important role in shaping the bacterial communities (Paula et al. 1992; Latour et al. 1996; Lazarovits and Nowak 1997; Garbeva et al. 2008). In fact, plant growth potential of PGPR is more stimulated in nutrient-deficient soil than in a nutrient-rich ones (Egamberdiyeva 2007). In a comparative study, Yanxia et al. (2009) showed that bacterial communities in the soybean rhizosphere were more stable in clayey soil comparing to the sandy soil (Yanxia et al. 2009). Both soil types and land use history parameters were shown to affect bacterial community to a greater extent than plant species. Different plant types (maize, oat, barley and grass) were cultivated under greenhouse conditions in soils with different land use histories. The previous land use was the main significant factor affecting the composition of the Burkholderia community (Salles et al. 2004). Also the soil type showed an effect on Pseudomonas diversity, but the soil factor exerted a preeminent influence on the bacterial communities' composition. Besides, Latour et al. (1996) evaluated the bacterial diversity of roots associated bacteria of two different plant species. They demonstrated that both soil type and host plant affect the bacterial diversity, though, the soil is the dominant factor (Latour et al. 1996). In another research study, microbial diversity has been assessed near Reaumuria negevensis plant growing in the Negev Desert (Saul-Tcherkas and Steinberger 2011). It has been demonstrated that bacterial communities' abundance is closely related to seasonal variations. In fact, Actinobacteria was the dominant phylum in all seasons except in winter. However, in winter season, Acidobacteria phylum reaches its highest density 
(56.3\%) and substitute Actinobacteria phylum, which decreases to 4.2\%. Beside, Proteobacteria phylum increases in the winter season. In the other hand, Bacteroidetes and Chloroflexi phyla were higher in the summer season and lower in winter and autumn, though, Gemmatimonadetes phylum increased in autumn.

Therefore, multiple ecological players shape the plant recruited microbiome. This peculiar plant associated bacterial assemblages are presumably involved in an adaptation strategy that allows the plants to overcome harsh conditions in arid lands.

\section{Functional services of plant-associated microbiomes in arid areas}

Considering the importance and the potential use of plant growth promoting rhizobacteria for agronomic and environmental applications, several studies focused not only on the bacterial diversity but also on the PGPR 'ecological role'. In this context, the interest in exploring PGPR bacteria naturally adapted to harsh arid ecosystems is widely increased especially for those associated to plants exposed to water shortage and salinity (Marasco et al. 2013b; Daffonchio et al. 2015).

In this context, a research work has been carried out to assess the microbial diversity and promoting growth potential of grapevine (Vitis vinifera) rhizobacteria sampled from three distinct Mediterranean sites: Tunisia, Egypt and Italy (Marasco et al. 2013a). Basing on cultivation dependent and independent approaches, the bacterial community associated to grapevine root system (root tissues, rhizosphere, and root-surrounding soil) has been assessed. A phylogenetic study showed the affiliation of the different root associated bacteria to five phyla: Acidobacteria, Actinobacteria, Firmicutes, Proteobacteria and Bacteroidetes. Alphaproteobacteria was dominant in all rhizospheric soils sampled from the different countries. According to DGGE analysis, soil endophyte fractions presented a limited diversity compared to the other root system samples. It has been explained that this low microbial diversity can be the result of a strong bacterial selection in the root system that imposes specific physiological requirements within the endosphere. However, a considerable endosphere and rhizosphere bacterial diversity has been reported in the different latitudinal sites examined. Despite this diversity, it has been demonstrated that bacterial PGP potential remained unchanged in the different rhizobacterial collections even though bio-pedo-climatic conditions were completely different in the studied sites (different cultivars, soil type and climate) (Figure 2). This functional redundancy in grapevine root associated bacteria proves the strong functional equilibrium of promoting growth bacteria despite the environmental variation. Such a property may protect 
grapevine from harsh conditions and ensure its survival regardless environmental constraints, mainly in arid systems

234 (Marasco et al. 2013a).

235 A recent work on the date palm rhizosphere in the oasis ecosystems of Southern Tunisia, reported that the shape of rhizobacterial communities is correlated with geo-climatic features along a north-south aridity transect (Ferjani et al. 2015). Such bacterial community segregation between the different oases was associated with the harsher conditions in the southern oases close to the Grand Erg Oriental desert, respect to the mountain oases. The cultivable bacteria associated to the date palm rhizosphere belonged to Proteobacteria, Actinobacteria and Firmicutes, with Gammaproteobacteria dominating followed by Actinobacteria. The majority ( $85 \%)$ of isolates affiliated to the different phyla showed multiple plant growth promotion activities (Table 1). Identifying environmental factors contributing to microbial community variation at a large spatial scale can help in assessing microbial communities usable for desert farming. Date palm root system showed a complex diversity that exhibited a reservoir of PGPR adapted to thrive in the harsh conditions of the desert oases (Ferjani et al. 2015). The rhizosphere of the halophyte Salicornia sp. obtained from the Sebkha and Chott hypersaline ecosystems in Southern Tunisia showed a high bacterial diversity and a large collection (475 isolates) of halophilic and halotolerant bacteria has been established. Twenty Halomonas isolates showed resistance to a wide set of abiotic stresses and performed different PGP activities in vitro mainly phosphate solubilisation, ammonia and indole-3acetic acid production and potential nitrogen fixation. These results demonstrate the relevant potential of these bacteria to promote plant growth under the harsh salinity and drought conditions (Mapelli et al. 2013). In another study, the rhizosphere of cactus plants growing on barren mineral substrates in North American deserts has been shown to contain dense layers of bacteria and fungi. The dominant bacterial groups were represented by Pseudomonads, Bacilli and Actinomycetes that have been shown to be able to dissolve several rock types and minerals, releasing significant amounts of useful minerals for plants (Bashan and de-Bashan 2010). Several PGPR strains may enhance root hair size and number, facilitating the mineral uptake capacity of the plant (de Freitas and Germida 1992).

257 An assessment of the bacterial diversity associated to pepper (Capsicum annuum L.) cultivated in a traditional farm subjected to desert farming practices in Egypt showed the presence of a dense and diverse bacterial population in the rhizosphere and the root surrounding soil. Conversely, the bacterial community associated to the endosphere was 
colonizers. Most of the isolates (95\%) presented in vitro multiple plant growth promoting (PGP) activities and stress resistance capabilities. It has been also demonstrated that under desert farming, PGP bacteria are able of enhancing plant photosynthetic activity and biomass synthesis (up to 40\%) under drought stress (Marasco et al. 2012).

To evaluate long-term agriculture impact on arid soil in organic desert farming in Sekem (Egypt), Koberl et al. (2011) analysed microbial communities of the desert soil as well as those associated with cultivated medicinal plants Matricaria chamomilla, Calendula, officinalis and Solanum distichum. The desert soil was dominated by two phylotypes affiliated to Ochrobactrum sp. and Rhodococcus sp. which were also found in all samples from the rhizosphere and endorhiza of all the three medicinal plants. However, the rhizosphere and the endosphere of the medicinal plants presented a clear plant-specific effect since they shared only $20 \%$ of the bacterial community with the bulk desert soil. It has been demonstrated that indigenous desert microorganisms promote plant health in desert agro-ecosystems via an antagonist potential towards phytopathogens (Koberl et al. 2011).

All these studies indicate that arid land conditions select efficient PGPR capable of resisting harsh conditions and to sustain crop production under the desert farming practices (Figure 1 and 2).

\section{Biotechnological potential of PGP microbes and feasibility of their application}

Many studies have shown the important role of associated root bacteria in increasing crop yield and soil fertility (Desai et al. 2012; Deivanai et al. 2014; Nadeem et al. 2014; Kumar et al. 2014) not only in the normal conditions but also under biotic and abiotic stresses. This potential is currently applied for desert farming (Koberl et al. 2011) and for restoration and reforestation of eroded desert lands (Chanway 1997; Bashan et al. 2012). It has been proved that one of the consistent strategies for enhancing in vivo effect of PGP microbes on plants is multiple inoculations and stress protecting bioformulations (Adesemoye et al. 2008; Wang et al. 2012).

Beside, PGPR contribute to protect plant health against fungal, bacterial, nematode and even viral diseases in arid environments which are propitious to phyto-pathogens attacks (Rodríguez-Díaz et al. 2008; Almaghrabi et al. 2013). Fungal biocontrol has been mostly explored given its wide extension and devastating effect on crop yield (Ait Kaki et al. 2013; Siddiqui 2006; Recep et al. 2009; Muñoz et al. 2009). A research study on rhizobacteria associated with some desert plants in Saudi Arabia has been carried out to identify and to select effective isolates against phytopathogenic fungi. This investigation allowed the identification of successful isolates to Bacillus spp., 

and antagonistic potentials, the strains have been proposed as biofertilizer candidates (El-Sayed et al. 2014). Nevertheless, the application of such inoculum in agrobiology, cannot cover the broad-spectrum disease control given the variability of cultivar varieties, environmental conditions and soil types. It can be only applied in niche applications especially with weakly domesticated crop in growth substrates lacking antagonists (Cassells and Rafferty-McArdle 2012). However, despite significant biocontrol activities against plant pathogens has been proved for PGPR in laboratory and in the greenhouse, field results are still uncertain since autochthonous community outcompete the added allochthonous formulation.

The biotechnological potential enclosed in the extreme arid and saline environments is not limited to the agriculture application. Raddadi et al. 2013 reported the production of halo-alkalitolerant endoglucanase by Paenibacillus tarimensis isolated from the inland saline system Chott El Fjej in South Tunisia. These cellulases were functional in a broad $\mathrm{pH}$ range, at high temperature and salt concentration up to $5 \mathrm{M} \mathrm{NaCl}$ and $4.6 \mathrm{M} \mathrm{KCl}$. Consequently, they are promising candidate for industrial applications (Raddadi et al. 2013). Strains and enzymes isolated from arid extreme environments could be applied in bioremediation of polluted soils (Mapelli et al. 2012), especially under phytoremediation approaches for those strains capable to thrive in the root ecosystem. Indeed, phytoremediation processes have been proposed for enhancing plant adaptation and growth in soil and water contaminated with organic pollutants (Afzal et al. 2014) (Figure 2).

Furthermore, arid environment present deficiency in nitrogen compound, which implies symbiotic association between nitrogen fixing organisms and plants to increase the level of nitrogen and the plant growth in arid lands. Rhizobia are widely described as the most efficient nitrogen fixing bacteria especially rhizobium-legume symbiosis system (Zahran et al. 1999). Moreover, Requena et al. reported a combination between PGPR, arbuscular mycorrhizal fungi and Rhizobium spp. isolated from semi-arid environment for legume plant inoculation to establish Mediterranean semi-arid ecosystems revegetation (Requena et al. 1997).

\section{Conclusion}

Drought stress is an environmental threat affecting plant yield and productivity. As discussed in this review, arid 
316 active in supporting plant improvement, health and resistance to drought stress. Major efforts have still to be

317 implemented for the understanding of the factors that regulate the plant microbe interactions in the root system and

318 the mechanisms that are behind the drought resistance conferred to the plants by the root-associated bacteria. As

319 well, despite a huge body of literature is available about PGPR, the ecological factors determining their recruitment

320 by the plant and the assemblage of effective bacterial communities in the rhizosphere and the endosphere remain

321 elusive. It is evident that the assemblage of these bacterial communities is driven by different ecological factors,

322 including soil type, land history, cultivar variety, abiotic stresses, geo-climatic factors and by the type of plant and

323 its growing conditions. However, we are still far from understanding the relative weight of these factors in the

324 establishment of the root meta-organism. The clarifications of these factors regulating the recruitment and the

325 assemblage of drought resistance-inducing PGPR communities by the plant roots will allow to move PGPR from a prominent biotechnological tools yet to be exploited for agricultural, environmental and industrial purposes to a huge implementable biotechnological resource for agriculture.

328

329

Acknowledgments

330

The authors thank for financial support the European Union in the ambit of project BIODESERT (EU FP7-CSA-SA research in the ambit of the laboratory projects LR MBA206 and LR11ES31.

333 
Adesemoye AO, Torbert HA, Kloepper JW (2008) Enhanced plant nutrient use efficiency with PGPR and AMF in 338 an integrated nutrient management system. Canadian journal of microbiology 54 (10):876-886. doi:10.1139/w08339081

Afzal M, Khan QM, Sessitsch A (2014) Endophytic bacteria: Prospects and applications for the phytoremediation of organic pollutants. Chemosphere 117c:232-242. doi: 10.1016/j.chemosphere.2014.06.078

Ait Kaki A, Kacem Chaouche N, Dehimat L, Milet A, Youcef-Ali M, Ongena M, Thonart P (2013) Biocontrol and Plant Growth Promotion Characterization of Bacillus Species Isolated from Calendula officinalis Rhizosphere. Indian journal of microbiology 53 (4):447-452. doi: 10.1007/s12088-013-0395-y

Almaghrabi OA, Massoud SI, Abdelmoneim TS (2013) Influence of inoculation with plant growth promoting rhizobacteria (PGPR) on tomato plant growth and nematode reproduction under greenhouse conditions. Saudi Journal of Biological Sciences 20 (1):57-61. doi: 10.1016/j.sjbs.2012.10.004

An S, Couteau C, Luo F, Neveu J, DuBow MS (2013) Bacterial diversity of surface sand samples from the Gobi and

350 Appuhn A, Joergensen RG (2006) Microbial colonization of roots as a function of plant species. Soil Biology \& 351 Biochemistry 38:1040-1051

Bae H, Sicher RC, Kim MS, Kim S-H, Strem MD, Melnick RL, Bailey BA (2009) The beneficial endophyte 353 Trichoderma hamatum isolate DIS 219b promotes growth and delays the onset of the drought response in 354 Theobroma cacao. Journal of experimental botany 60 (11):3279-3295

Backhaus S, Wiehl D, Beierkuhnlein C, Jentsch A, Wellstein C (2014) Warming and drought do not influence the palatability of Quercus pubescens willd leaves of four European provenances. Arthropod-Plant Interactions 8 357 (4):329-337. doi: 10.1007/s11829-014-9313-4

Bashan Y, de-Bashan LE (2010) Microbial populations of arid lands and their potential for restoration of deserts. In: Soil biology and agriculture in the tropics. Springer, pp 109-137

Bashan Y, Salazar BG, Moreno M, Lopez BR, Linderman RG (2012) Restoration of eroded soil in the Sonoran Desert with native leguminous trees using plant growth-promoting microorganisms and limited amounts of compost and water. Journal of environmental management 102:26-36. doi:10.1016/j.jenvman.2011.12.032

Begley M, Gahan CG, Hill C (2002) Bile stress response in Listeria monocytogenes LO28: adaptation, cross10.1371/journal.pbio.0040023 
Cankar K, Kraigher H, Ravnikar M, Rupnik M (2005) Bacterial endophytes from seeds of Norway spruce (Picea abies L. Karst). FEMS Microbiology Letters 244 (2):341-345. doi: c10.1016/j.femsle.2005.02.008

Cassells A, Rafferty-McArdle S (2012) Priming of Plant Defenses by PGPR against Fungal and Bacterial Plant Foliar Pathogens. In: Maheshwari DK (ed) Bacteria in Agrobiology: Stress Management. Springer Berlin Heidelberg, pp 1-26. doi: 10.1007/978-3-642-23465-1_1

Cavaglieri LOJ, Etcheverry M (2009) Rhizosphere microbial community structure at different maize plant growth stages and root locations. Microbiological Research 164:391-399

Chanal A, Chapon V, Benzerara K, Barakat M, Christen R, Achouak W, Barras F, Heulin T (2006) The desert of Tataouine: an extreme environment that hosts a wide diversity of microorganisms and radiotolerant bacteria. Environmental Microbiology 8 (3):514-525. doi: 10.1111/j.1462-2920.2005.00921.x

Chanway CP (1997) Inoculation of Tree Roots with Plant Growth Promoting Soil Bacteria: An Emerging Technology for Reforestation. Forest Science 43 (1):99-112

Colica G, Li H, Rossi F, Li D, Liu Y, De Philippis R (2014) Microbial secreted exopolysaccharides affect the hydrological behavior of induced biological soil crusts in desert sandy soils. Soil Biology and Biochemistry 68:6270. doi: 10.1016/j.soilbio.2013.09.017

Compant S, Duffy B, Nowak J, Clement C, Barka EA (2005) Use of plant growth-promoting bacteria for biocontrol of plant diseases: principles, mechanisms of action, and future prospects. Applied and environmental microbiology 71 (9):4951-4959. doi: 10.1128/aem.71.9.4951-4959.2005

Costacurta A, Vanderleyden J (1995) Synthesis of phytohormones by plant-associated bacteria. Critical reviews in microbiology $21(1): 1-18$

Couillerot O, Prigent-Combaret C, Caballero-Mellado J, Moënne-Loccoz Y (2009) Pseudomonas fluorescens and closely-related fluorescent pseudomonads as biocontrol agents of soil-borne phytopathogens. Letters in applied microbiology 48 (5):505-512

Daffonchio D, Hirt H, Berg G (2015) Plant-Microbe Interactions and Water Management in Arid and Saline Soils. In: Lugtenberg B (ed) Principles of Plant-Microbe Interactions. Springer International Publishing, pp 265-276. doi: 10.1007/978-3-319-08575-3_28

Danhorn T, Fuqua C (2007) Biofilm formation by plant-associated bacteria. Annu Rev Microbiol 61:401-422

De-Bashan LE, Hernandez JP, Nelson KN, Bashan Y, Maier RM (2010) Growth of Quailbush in Acidic, Metalliferous Desert Mine Tailings: Effect of Azospirillum brasilense Sp6 on Biomass Production and Rhizosphere Community Structure. Microbial ecology 60 (4):915-927. doi: 10.1007/s00248-010-9713-7

De Freitas JR, Germida JJ (1992) Growth promotion of winter wheat by fluorescent pseudomonads under growth chamber conditions. Soil Biology and Biochemistry 24 (11):1127-1135. doi: 10.1016/0038-0717(92)90063-4

Deivanai S, Bindusara AS, Prabhakaran G, Bhore SJ (2014) Culturable bacterial endophytes isolated from Mangrove tree (Rhizophora apiculata Blume) enhance seedling growth in Rice. Journal of natural science, biology, and medicine 5 (2):437-444. doi: 10.4103/0976-9668.136233

Desai S, Grover M, Amalraj EL, Kumar GP, Ahmed SKM (2012) Exploiting Plant Growth Promoting Rhizomicroorganisms for Enhanced Crop Productivity. In: Satyanarayana T, Johri BN (eds) Microorganisms in Sustainable Agriculture and Biotechnology. Springer Netherlands, pp 227-241. doi: 10.1007/978-94-007-2214-9_12 
Dias ACF, Costa FEC, Andreote FD, Lacava PT, Teixeira MA, Assumpção LC, Araújo WL, Azevedo JL, Melo IS (2009) Isolation of micropropagated strawberry endophytic bacteria and assessment of their potential for plant growth promotion. World Journal of Microbiology and Biotechnology 25 (2):189-195. doi:10.1007/s11274-0089878-0

DiRuggiero J, Wierzchos J, Robinson CK, Souterre T, Ravel J, Artieda O, Souza-Egipsy V, Ascaso C (2013) Microbial colonization of chasmoendolithic habitats in the hyper-arid zone of the Atacama Desert. Biogeosciences 10 (4):2439-2450. doi: 10.5194/bg-10-2439-2013

Doty SL (2008) Enhancing phytoremediation through the use of transgenics and endophytes. New Phytologist 179 (2):318-333

Duineveld BM, Rosado AS, van Elsas JD, van Veen JA (1998) Analysis of the Dynamics of Bacterial Communities in the Rhizosphere of the Chrysanthemum via Denaturing Gradient Gel Electrophoresis and Substrate Utilization Patterns. Applied and environmental microbiology 64 (12):4950-4957

Egamberdiyeva D (2007) The effect of plant growth promoting bacteria on growth and nutrient uptake of maize in two different soils. Applied Soil Ecology 36 (2-3):184-189. doi: 10.1016/j.apsoil.2007.02.005

El-Sayed WS, Akhkha A, El-Naggar MY, Elbadry M (2014) In vitro antagonistic activity, plant growth promoting traits and phylogenetic affiliation of rhizobacteria associated with wild plants grown in arid soil. Frontiers in microbiology 5

Etesami H, Mirsyed Hosseini H, Alikhani HA (2014) In planta selection of plant growth promoting endophytic bacteria for rice (Oryza sativa L.). Journal of soil science and plant nutrition 14:491-503

Falcäo LL, Silva-Werneck JO, Vilarinho BR, da Silva JP, Pomella AWV, Marcellino LH (2014) Antimicrobial and plant growth-promoting properties of the cacao endophyte Bacillus subtilis ALB629. Journal of Applied Microbiology 116 (6):1584-1592. doi:10.1111/jam.12485

Ferjani R, Marasco R, Rolli E, Cherif H, Cherif A, Gtari M, Boudabous A, Daffonchio D, Ouzari H-I (2015) The Date Palm Tree Rhizosphere Is a Niche for Plant Growth Promoting Bacteria in the Oasis Ecosystem. BioMed Research International 2015. doi: 10.1155/2015/153851

Forchetti G, Masciarelli O, Alemano S, Alvarez D, Abdala G (2007) Endophytic bacteria in sunflower (Helianthus annuus L.): isolation, characterization, and production of jasmonates and abscisic acid in culture medium. Applied microbiology and biotechnology $76(5): 1145-1152$

Gabriele W, Regine N, Horst B (2001) Variation of Microbial Communities in Soil, Rhizosphere, and Rhizoplane in Response to Crop Species, Soil Type, and Crop Development. Applied and environmental microbiology 67 (12):5849-5854

Germaine KJ, Liu X, Cabellos GG, Hogan JP, Ryan D, Dowling DN (2006) Bacterial endophyte-enhanced phytoremediation of the organochlorine herbicide 2, 4-dichlorophenoxyacetic acid. FEMS microbiology ecology 57 (2):302-310

Garbeva P, Van Elsas JD, Van Veen JA (2008) Rhizosphere microbial community and its response to plant species and soil history. Plant Soil 302:19-32 
450 Hallmann J, Quadt-Hallmann A, Mahaffee W, Kloepper J (1997) Bacterial endophytes in agricultural crops. 451 Canadian journal of microbiology 43 (10):895-914

452 Haney CH, Samuel BS, Bush J, Ausubel FM (2015) Associations with rhizosphere bacteria can confer an adaptive 453 advantage to plants. Nature Plants

Jorquera MA, Shaharoona B, Nadeem SM, de la Luz Mora M, Crowley DE (2012) Plant Growth-Promoting 455 Rhizobacteria Associated with Ancient Clones of Creosote Bush (Larrea tridentata). Microbial ecology 64 456 (4):1008-1017. doi: 10.1007/s00248-012-0071-5

457 Klay I, Pirrello J, Riahi L, Bernadac A, Cherif A, Bouzayen M, Bouzid S (2014) Ethylene Response Factor S1-ERF. 458 B. 3 Is Responsive to Abiotic Stresses and Mediates Salt and Cold Stress Response Regulation in Tomato. The 459 Scientific World Journal 2014

460 Koberl M, Muller H, Ramadan EM, Berg G (2011) Desert farming benefits from microbial potential in arid soils and 461 promotes diversity and plant health. PloS one 6 (9):e24452. doi: 10.1371/journal.pone.0024452

462 Kuiper I, Lagendijk EL, Bloemberg GV, Lugtenberg BJJ (2004) Rhizoremediation: A Beneficial Plant-Microbe 463 Interaction. Molecular Plant-Microbe Interactions 17 (1):6-15. doi:10.1094/MPMI.2004.17.1.6

464 Kumar A, Maurya BR, Raghuwanshi R (2014) Isolation and characterization of PGPR and their effect on growth, 465 yield and nutrient content in wheat (Triticum aestivum L.). Biocatalysis and Agricultural Biotechnology (0). doi: $466 \quad 10.1016 /$ j.bcab.2014.08.003

467 Latour X, Corberand T, Laguerre G, Allard F, Lemanceau P (1996) The composition of fluorescent pseudomonad 468 populations associated with roots is influenced by plant and soil type. Applied and environmental microbiology 62 469 (7):2449-2456

470 Laukkanen H, Soini H, Kontunen-Soppela S, Hohtola A, Viljanen M (2000) A mycobacterium isolated from tissue 471 cultures of mature Pinus sylvestris interferes with growth of Scots pine seedlings. Tree Physiology 20:915-920

Lazarovits G, Nowak J (1997) Rhizobacteria for Improvement of Plant Growth and Establishment. Hort Science 32 473 (2):188-192

474 Lodewyckx C, Vangronsveld J, Porteous F, Moore ER, Taghavi S, Mezgeay M, der Lelie Dv (2002) Endophytic 475 bacteria and their potential applications. Critical Reviews in Plant Sciences 21 (6):583-606

476 Lopez B, Bashan Y, Bacilio M (2011) Endophytic bacteria of Mammillaria fraileana, an endemic rock-colonizing 477 cactus of the southern Sonoran Desert. Archives of microbiology 193 (7):527-541. doi:10.1007/s00203-011-0695-8

478 Manter DK, Delgado JA, Holm DG, Stong RA (2010) Pyrosequencing reveals a highly diverse and cultivar-specific 479 bacterial endophyte community in potato roots. Microbial ecology 60 (1):157-166

480 Mapelli F, Marasco R, Balloi A, Rolli E, Cappitelli F, Daffonchio D, Borin S (2012) Mineral-microbe interactions: 481 Biotechnological potential of bioweathering. Journal of Biotechnology 157 (4):473-481. doi: $482 \quad 10.1016 /$ j.jbiotec.2011.11.013 
Mapelli F, Marasco R, Rolli E, Barbato M, Cherif H, Guesmi A, Ouzari I, Daffonchio D, Borin S (2013) Potential for plant growth promotion of Rhizobacteria associated with Salicornia growing in Tunisian hypersaline soils. BioMed research international 2013

Marasco R, Rolli E, Ettoumi B, Vigani G, Mapelli F, Borin S, Abou-Hadid AF, El-Behairy UA, Sorlini C, Cherif A, Zocchi G, Daffonchio D (2012) A drought resistance-promoting microbiome is selected by root system under desert farming. PloS one 7 (10):e48479. doi: 10.1371/journal.pone.0048479

Marasco R, Rolli E, Fusi M, Cherif A, Abou-Hadid A, El-Bahairy U, Borin S, Sorlini C, Daffonchio D (2013a) Plant growth promotion potential is equally represented in diverse grapevine root-associated bacterial communities from different biopedoclimatic environments. BioMed research international 2013

Marasco R, Rolli E, Vigani G, Borin S, Sorlini C, Ouzari H, Zocchi G, Daffonchio D (2013b) Are droughtresistance promoting bacteria cross-compatible with different plant models? Plant signaling \& behavior 8 (10). doi: $10.4161 /$ psb. 26741

McCully M (2005) The rhizosphere: the key functional unit in plant/soil/microbial interactions in the field. Implications for the understanding of allelopathic effects. In: Proceedings of the 4th World Congress on Allelopathy, 2005. pp 21-26

Melnick RL, Bailey BA, Backman PA (2013) Bacterial endophytes of perennial crops for management of plant disease. In: Bacteria in Agrobiology: Disease Management. Springer, pp 49-76

Müller H, Berg C, Landa B.B, Auerbach, Moissl-Eichinger C, Berg G (2015) Plant genotype-specific archaeal and bacterial endophytes but similar Bacillus antagonists colonize Mediterranean olive trees. Frontiers in Microbiology 6. doi:10.3389/fmicb. 2015.00138

Muñoz Z, Moret A, Garcés S (2009) Assessment of chitosan for inhibition of Colletotrichum sp. on tomatoes and grapes. Crop Protection 28 (1):36-40. doi: 10.1016/j.cropro.2008.08.015

Nadeem SM, Ahmad M, Zahir ZA, Javaid A, Ashraf M (2014) The role of mycorrhizae and plant growth promoting rhizobacteria (PGPR) in improving crop productivity under stressful environments. Biotechnology Advances 32 (2):429-448. doi: 10.1016/j.biotechadv.2013.12.005

Nagy ML, Perez A, Garcia-Pichel F (2005) The prokaryotic diversity of biological soil crusts in the Sonoran Desert (Organ Pipe Cactus National Monument, AZ). FEMS microbiology ecology 54 (2):233-245. doi: 10.1016/j.femsec.2005.03.011

Neilands JB (1995) Siderophores: Structure and function of microbial iron transport compounds. Journal of Biological Chemistry 270 (45):26723-26726

Neilson JW, Quade J, Ortiz M, Nelson WM, Legatzki A, Tian F, LaComb M, Betancourt JL, Wing RA, Soderlund CA, Maier RM (2012) Life at the hyperarid margin: novel bacterial diversity in arid soils of the Atacama Desert, Chile. Extremophiles: life under extreme conditions 16 (3):553-566. doi: 10.1007/s00792-012-0454-z

Othman AA, Amer WM, Fayez M, Hegazi N (2004) Rhizosheath of Sinai desert plants is a potential repository for associative diazotrophs. Microbiological research 159 (3):285-293

Park MS, Jung SR, Lee MS, Kim KO, Do JO, Lee KH, Kim SB, Bae KS (2005) Isolation and characterization of bacteria associated with two sand dune plant species, Calystegia soldanella and Elymus mollis. Journal of Microbiology-Seoul- 43 (3):219 
Paula MA, Urquiaga S, Siqueira JO, Döbereiner J (1992) Synergistic effects of vesicular-arbuscular mycorrhizal fungi and diazotrophic bacteria on nutrition and growth of sweet potato (Ipomoea batatas). Biol Fertil Soils 14 (1):61-66. doi: 10.1007/BF00336304

Pirttilä AM, Laukkanen H, Pospiech H, Myllylä R, Hohtola A (2000) Detection of intracellular bacteria in the buds of Scotch Pine (Pinus sylvestris L.) by in situ hybridization. Applied and Environmental Microbiology 66: 3073 3077

Pointing SB, Belnap J (2012) Microbial colonization and controls in dryland systems. Nature Reviews Microbiology 10 (8):551-562. doi: 10.1038/nrmicro2831

Qin S, Xing K, Jiang J-H, Xu L-H, Li W-J (2011) Biodiversity, bioactive natural products and biotechnological potential of plant-associated endophytic Actinobacteria. Applied microbiology and biotechnology 89 (3):457-473

Raddadi N, Cherif A, Daffonchio D, Fava F (2013) Halo-alkalitolerant and thermostable cellulases with improved tolerance to ionic liquids and organic solvents from Paenibacillus tarimensis isolated from the Chott El Fejej, Sahara desert, Tunisia. Bioresource technology 150:121-128. doi: 10.1016/j.biortech.2013.09.089

Recep K, Fikrettin S, Erkol D, Cafer E (2009) Biological control of the potato dry rot caused by Fusarium species using PGPR strains. Biological Control 50 (2):194-198

Requena N, Jimenez I, Toro M, Barea JM (1997) Interactions between plant-growth promoting rhizobacteria (PGPR), arbuscular mycorrhizal fungi and Rhizobium spp. in the rhizosphere of Anthyllis cytisoides, a model legume for revegetation in mediterranean semi-arid ecosystems. New Phytol 136 : 667-677

Rhoden SA, Garcia A, Santos E Silva MC, Azevedo JL, Pamphile JA (2015) Phylogenetic analysis of endophytic bacterial isolates from leaves of the medicinal plant Trichilia elegans A. Juss. (Meliaceae). Genetics and Molecular Research 14 (1):1515-1525. doi: 10.4238/2015.February.20.7

Richardson AE (2001) Prospects for using soil microorganisms to improve the acquisition of phosphorus by plants. Functional Plant Biology 28 (9):897-906

Richardson AE, Barea J-M, McNeill AM, Prigent-Combaret C (2009) Acquisition of phosphorus and nitrogen in the rhizosphere and plant growth promotion by microorganisms. Plant and soil 321 (1-2):305-339

Rodríguez-Díaz M, Rodelas-Gonzalés B, Pozo-Clemente C, Martínez-Toledo MV, González-López J (2008) A review on the taxonomy and possible screening traits of plant growth promoting rhizobacteria. Plant-Bacteria Interactions: Strategies and Techniques to Promote Plant Growth: 55-80

Rosenblueth M, Martínez-Romero E (2006) Bacterial endophytes and their interactions with hosts. Molecular plantmicrobe interactions $19(8): 827-837$

Ryan RP, Germaine K, Franks A, Ryan DJ, Dowling DN (2008) Bacterial endophytes: recent developments and applications. FEMS Microbiol Lett 278 (1):1-9. doi:10.1111/j.1574-6968.2007.00918.x

Saharan B, Nehra V (2011) Plant growth promoting rhizobacteria: a critical review. Life Sci Med Res 21:1-30

Salles JF, Van Veen JA, Van Elsas JD (2004) Multivariate analyses of Burkholderia species in soil: effect of crop and land use history. Applied and environmental microbiology 70 (7):4012-4020

Sandhya V, Ali SZ, Venkateswarlu B, Reddy G, Grover M (2010) Effect of osmotic stress on plant growth promoting Pseudomonas spp. Archives of microbiology 192 (10):867-876. doi: 10.1007/s00203-010-0613-5 
560 Sgroy V, Cassán F, Masciarelli O, Del Papa MF, Lagares A, Luna V (2009) Isolation and characterization of 561 endophytic plant growth-promoting (PGPB) or stress homeostasis-regulating (PSHB) bacteria associated to the halophyte Prosopis strombulifera. Applied microbiology and Biotechnology 85 (2):371-381

563 Shelef O, Helman Y, Friedman ALL, Behar A, Rachmilevitch S (2013) Tri-party underground symbiosis between a 564 weevil, bacteria and a desert plant. PloS one 8 (11). doi: 10.1371/journal.pone.0076588

Shukla KP, Sharma S, Singh NK, Singh V, Tiwari K, Singh S (2013) Nature and role of root exudates: Efficacy in bioremediation. African Journal of Biotechnology 10 (48):9717-9724

Siddiqui ZA (2006) PGPR: Prospective biocontrol agents of plant pathogens. In: PGPR: biocontrol and 568 biofertilization. Springer, pp 111-142

569 Spaepen S, Vanderleyden J, Remans R (2007) Indole-3-acetic acid in microbial and microorganism-plant signaling. 570 FEMS microbiology reviews 31 (4):425-448

571 Strobel G (2007) Plant-Associated Microorganisms (Endophytes) as a New Source of Bioactive Natural Products. 572 Medicinal Plant Biotechnology: From Basic Research to Industrial Applications:49-72

573 Ulrich K, Ulrich A, Ewald D (2008) Paenibacillus - a predominant endophytic bacterium colonizing tissue cultures 574 of woody plants. Plant Cell Tissue and Organ Culture 93:347-351 Van Loon L, Bakker P, Pieterse C (1997) Mechanisms of PGPR-induced resistance against pathogens. Van Overbeek L, Van Elsas JD (2008) Effects of plant genotype and growth stage on the structure of bacterial communities associated with potato (Solanum tuberosum L.). FEMS microbiology ecology 64:283-296

Wang CJ, Yang W, Wang C, Gu C, Niu DD, Liu HX, Wang YP, Guo JH (2012) Induction of drought tolerance in cucumber plants by a consortium of three plant growth-promoting rhizobacterium strains. PloS one 7 (12):e52565. doi: 10.1371/journal.pone.0052565

581 Whitford WG (2002) Ecology of desert systems. Academic Press,

Xia Y, Greissworth E, Mucci C, Williams MA, De Bolt S (2013) Characterization of culturable bacterial endophytes 583 of switchgrass (Panicum virgatum L.) and their capacity to influence plant growth. GCB Bioenergy 5 (6):674-682

Xu Y, Rossi F, Colica G, Deng S, De Philippis R, Chen L (2013) Use of cyanobacterial polysaccharides to promote shrub performances in desert soils: a potential approach for the restoration of desertified areas. Biol Fertil Soils 49 (2):143-152

587 Yanxia Xu GW, Jian J, Junjie L, Qiuying Z, Xiaobing L (2009) Bacterial communities in soybean rhizosphere in 588 response to soil type, soybean genotype, and their growth stage. Soil Biology \& Biochemistry 41:919-925

589 Zahran H.H (1999) Rhizobium-Legume Symbiosis and Nitrogen Fixation under Severe Conditions and in an Arid 590 Climate. Microbiology and Molecular biology Reviews: 968-989

591 Zhang N, Wang D, Liu Y, Li S, Shen Q, Zhang R (2014) Effects of different plant root exudates and their organic 592 acid components on chemotaxis, biofilm formation and colonization by beneficial rhizosphere-associated bacterial 
594 Zinniel DK, Lambrecht P, Harris NB, Feng Z, Kuczmarski D, Higley P, Ishimaru CA, Arunakumari A, Barletta RG,

595 Vidaver AK (2002) Isolation and characterization of endophytic colonizing bacteria from agronomic crops and

596 prairie plants. Applied and environmental microbiology 68 (5):2198-2208

597

598

599

600 
Figure 1: Location in world map and distribution of the arid lands and desert ecosystems sites where studies were conducted on the diversity of plant-associated microbial assemblages as reported in Table 1. Microbial communities' diversity is shaped by the abiotic factors (arid conditions) and by the plant-related factors (Fig. 2). Microorganisms were detected by culture-dependent (green dots and letters), and-independent approaches (red dots and letters) or both (black dot). Gammaproteobacteria (Gp) are the most encountered class in almost all the prospected sites. Alphaproteobacteria (Ap) and Firmicutes (F) showed also high occurrence. Independently from each bacterial community components, PGP functional redundancy is noticed leading to functional services. These PGPR from arid lands hold the potential to sustain crop production under the desert farming practices. Detected Phyla: P, Proteobacteria (Gp, Gammaproteobacteria; Ps, Pseudomonas; Az, Azotobacter; En, Enterobacter; Ch, Chryseomonas; Hm, Halomonas; Ku, Kushneria; Cr, Chromohalobacter); (Ap, Alphaproteobacteria; Or, Ochrabactrum; Ag, Agrobacterium); (Bp, Betaproteobacteria; Ac, Achromobacter); F, Firmicutes (Bc, Bacillus; Ly, Lysinibacillus; Br, Brevibacillus; Pn, Paenibacillus; Vg, Virgibacillus; Mr, Marinococcus); A, Actinobacteria (Rh, Rhodococcus; Ns, Nesterenkonia) and B, Bacteroidetes; (Sp, Sphingobacteria).

Figure 2: Plant associated bacterial assemblages: Ecological drivers, functions and applications.

617 In arid environments, plants recruit diverse bacterial communities to undertake the harsh environmental conditions. Within the phyllosphere and the rhizosphere plant compartments, bacteria colonizing the rhizosphere and the endosphere are the most investigated. They are shaped by several ecological drivers. Plant related factors determine the plant associated microbiome depending on the plant type, its growth stage and the composition of its root exudates. Beside, plant genotype is also a crucial factor in determining plant associated bacteria depending on the cultivar or the ecotype. Abiotic stresses contribute to this bacterial communities' recruitment. Abiotic factors are related to the typical climate of the arid lands and deserts characterized by seasonal variations, high UV radiations and temperature and low precipitations. The biological state of agricultural soils and the land use history that affect the soil nutrients richness, structure, moisture and salinity, are also key ecological drivers. Despite the microbial diversity of PGP bacteria, functional redundancy has been shown. It proves a strong functional equilibrium although 
627 the environmental variations. This distinctive characteristic can preserve plants from harsh conditions and ensure

628 their survival regardless arid systems environmental constraints. These functions consist on plant growth promotion

629 under harsh salinity and drought conditions, phytohormones production, facilitation of mineral and nutrient

630 availability and uptake capacity as well as the promotion of plant health via antagonistic potential towards

631 phytopathogens. PGP bacteria are endowed with diverse biotechnological potentials. They can be evolved in

632 agricultural applications as biofertilizers and agents for phytopathogens biocontrol. They may be further used in

633 phytoremediation for xenobiotic polluted soils. PGP bacteria can also be employed in industrial application, such as

634 detergents, textiles and paper industries, thanks to their high resistance to salinity and high temperature in addition to

635 their thermostability and tolerance of harsh chemical compounds.

636

637 


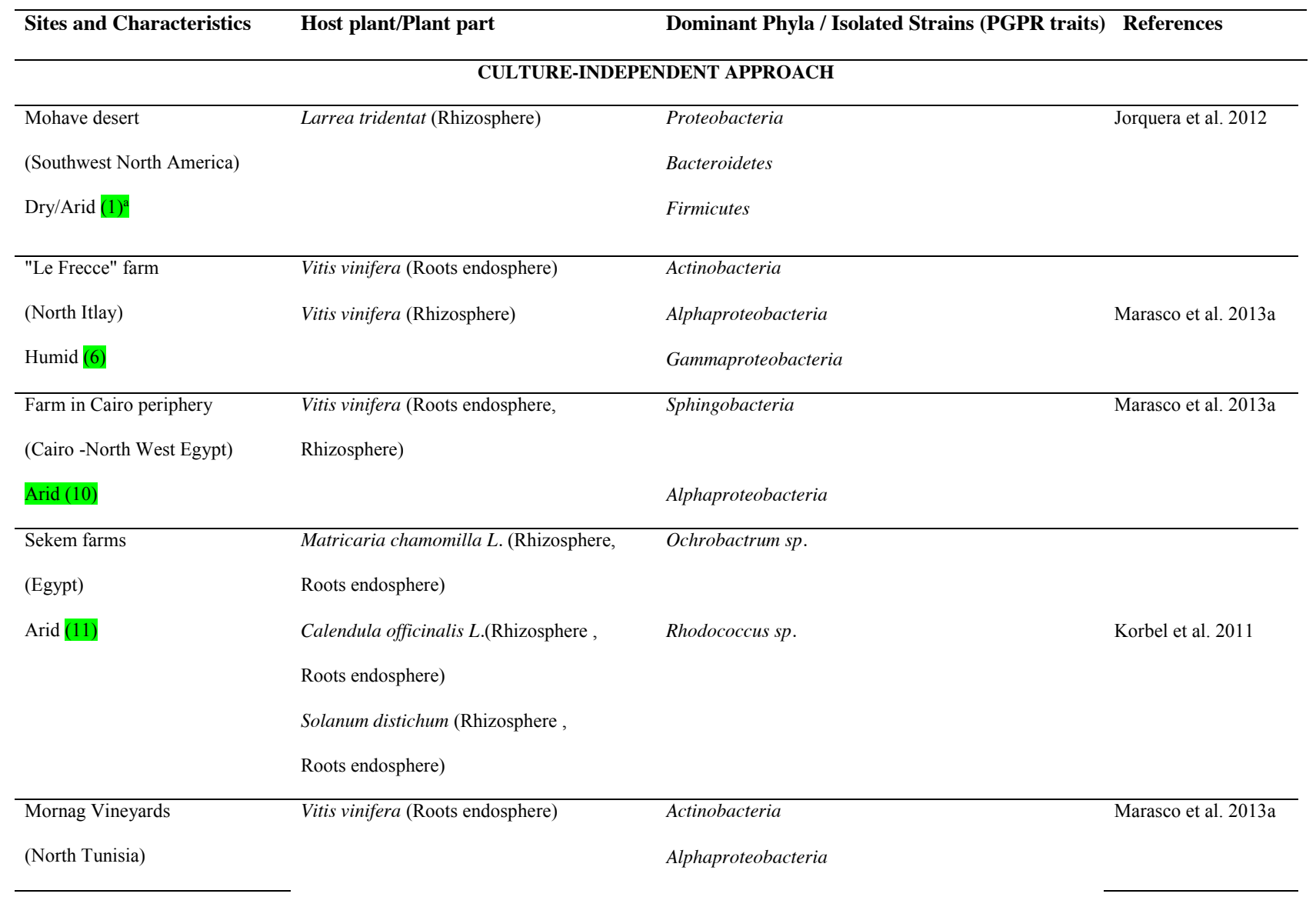




\begin{tabular}{|c|c|c|c|}
\hline \multirow[t]{4}{*}{ Semi-arid (7) } & \multirow{4}{*}{ Vitis vinifera (Rhizosphere) } & Betaproteobacteria & \\
\hline & & Sphingobacteria & \\
\hline & & Alphaproteobacteria & \\
\hline & & Betaproteobacteria & \\
\hline Sebkha and Chott & \multirow{3}{*}{ Salicornia (Rhizosphere) } & Betaproteobacteria & \multirow[t]{3}{*}{ Mapelli et al. 2013} \\
\hline (Southern Tunisia) & & Alphaproteobacteria & \\
\hline Hypersaline soils (8) & & Firmicutes & \\
\hline
\end{tabular}

\section{CULTURE-DEPENDENT APPROACH}

\begin{tabular}{|c|c|c|c|}
\hline Arid land & Pennisetum glaucum L (Rhizosphere) & Pseudomonas (PS, $\mathrm{PH}, \mathrm{Si}, \mathrm{Am})^{\mathrm{b}}$ & Sandhya et al. 2010 \\
\hline India & Pennisetum glaucum L (Rhizosphere) & & \\
\hline Arid (13) & Zea mays L (Rhizosphere) & & \\
\hline Southern Sonoran Desert & Mammillaria fraileana (Endosphere, Roots & Azotobacter vinelandii (NF) & Lopez et al. 2011 \\
\hline (North America) & cortex) & & \\
\hline \multirow[t]{3}{*}{ Subtropical, hot, dry (3) } & Mammillaria fraileana (Endosphere, Roots & Pseudomonas Putida (PS) & \\
\hline & & Enterobacter sakazakii (PS) & \\
\hline & & Bacillus megaterium(PS) & \\
\hline El Bebedero saline & Prosopis strombulifera (Roots endosphere) & Lysinibacillus fusiformis (NF, $\mathrm{PH})$ & Sgroy et al. 2009 \\
\hline
\end{tabular}




\begin{tabular}{|c|c|c|c|}
\hline (San Luis, Argentina) & & Bacillus subtilis (NF, ACC, $\mathrm{PH}$ ) & \\
\hline \multirow{5}{*}{ Saline system (5) } & & Brevibacterium halotolerans (NF, ACC, AF, $\mathrm{PH})$ & \\
\hline & & Bacillus licheniformis (NF, ACC, $\mathrm{PH})$ & \\
\hline & & Bacillus pumilus (NF, ACC, $\mathrm{AF}, \mathrm{PH})$ & \\
\hline & & Achromobacter xylosoxidans (NF, ACC, $\mathrm{PH})$ & \\
\hline & & Pseudomonas putida (Si, NF, ACC, $\mathrm{PH})$ & \\
\hline Tae-An sand dunes & Calystegia soldanella (Rhizosphere) & Gammaproteobacteria & Park et al. 2005 \\
\hline (Chungnam- South Korea) & & Bacteroidetes, Actinobacteria & \\
\hline \multirow[t]{5}{*}{ Desert (14) } & Calystegia soldanella (Roots) & Gammaproteobacteria & \\
\hline & & Alphaproteobacteria, Actinobacteria & \\
\hline & Elymus mollis (Rhizosphere) & Gammaproteobacteria, & \\
\hline & & Bacteroidetes, Actinobacteria & \\
\hline & Elymus mollis (Roots) & Gammaproteobacteria & \\
\hline Sinai desert & Panicum turgidum (Rhizosheath) & Paenibacillus macerans (NF) & Othman et al. 2004 \\
\hline (Egypt) & & Bacillus circulans (NF) & \\
\hline \multirow[t]{4}{*}{ Arid to desert (12) } & & Agrobacterium radiobacter $(\mathrm{NF})$ & \\
\hline & & Chryseomonas luteola (NF) & \\
\hline & & Bacillus circulans (NF) & \\
\hline & Panicum turgidum (Intact root) & Bacillus circulans (NF) & \\
\hline
\end{tabular}




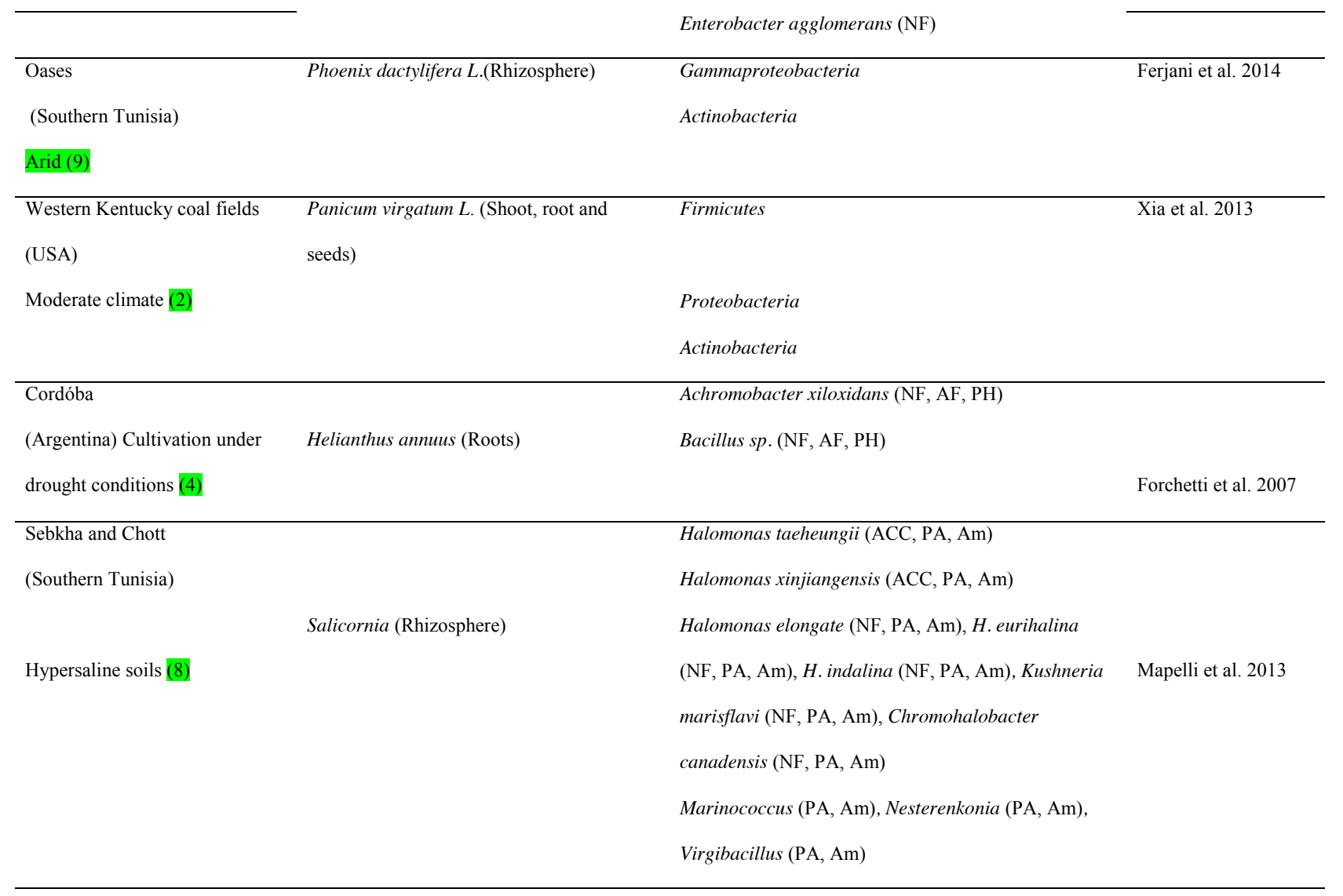


(a), Site number in Figure 1; (b), Plant Growth Promoting activities: Nitrogen Fixation (NF), Phosphate Solubilization (PS), Phytohormones production (PH), Siderephore production ( $\mathrm{Si}$ ), Ammonia production (Am), 1 aminocyclo-propane-1-carboxylate deaminase production (ACC), antifungal activity (AF), Protease Activity (PA). 


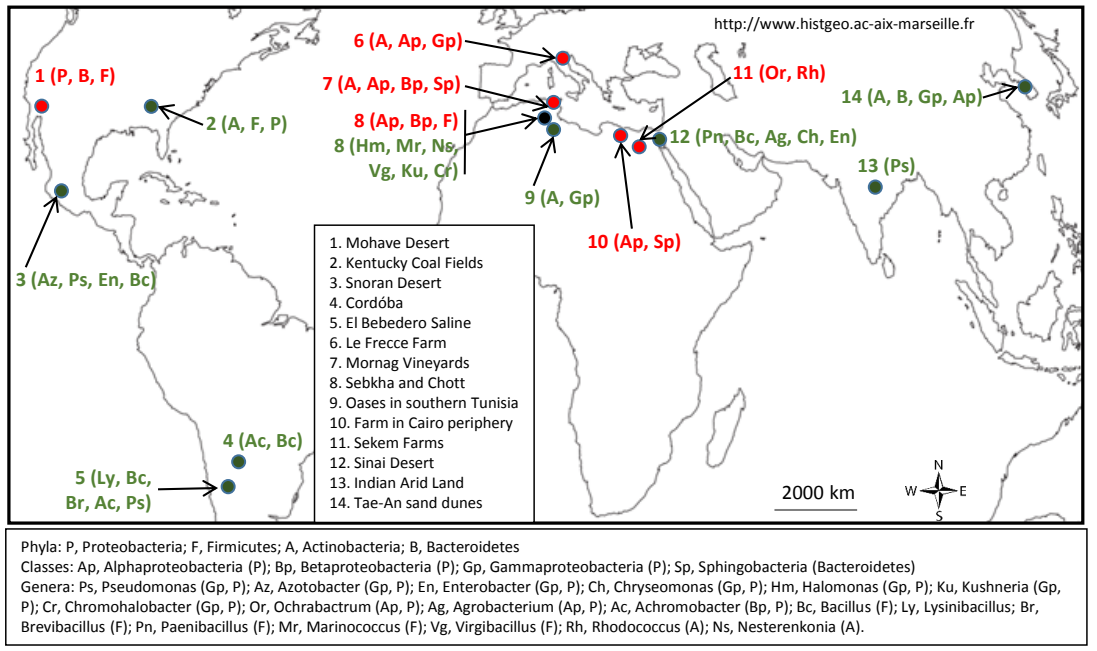




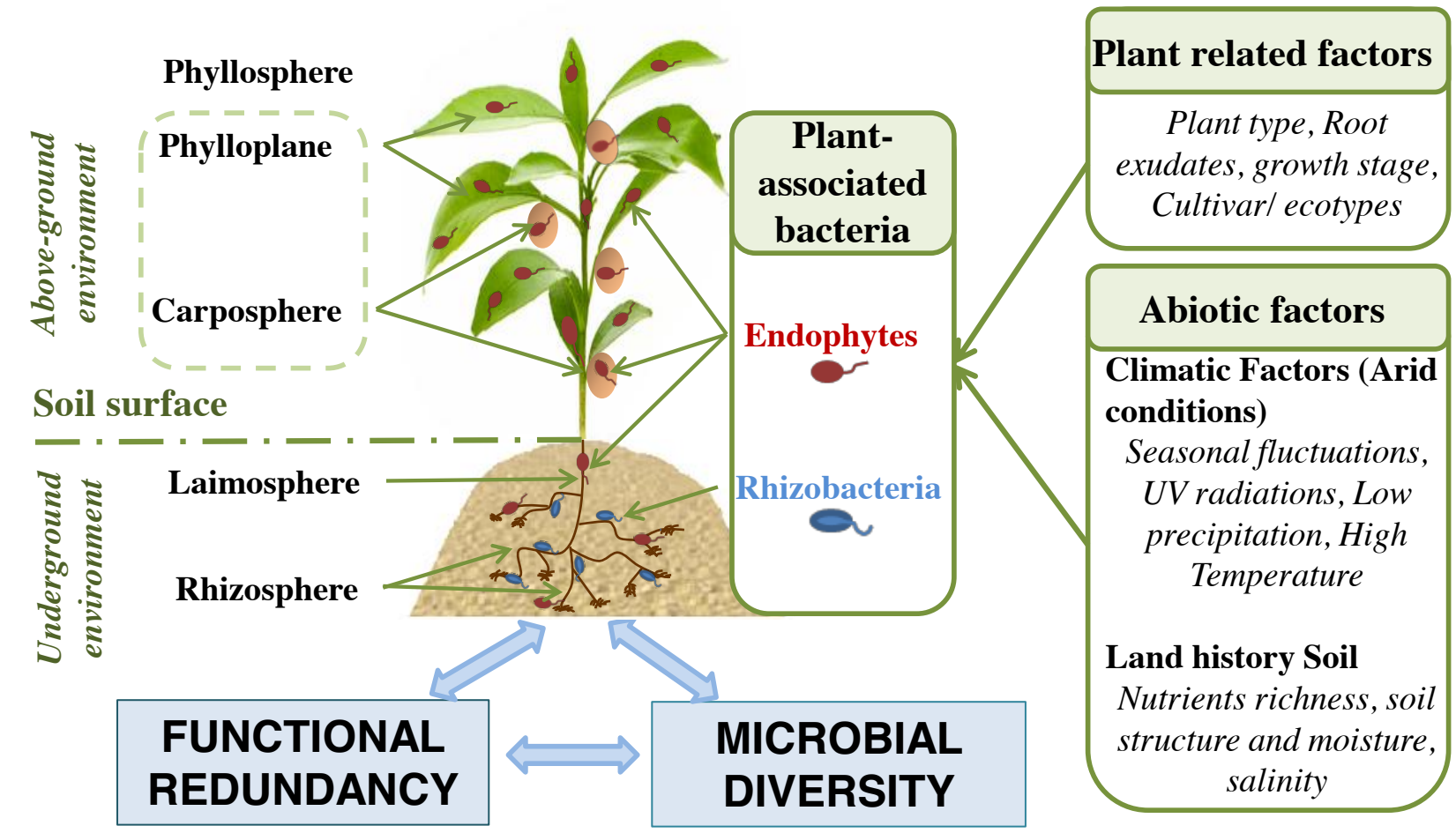

\begin{tabular}{|l|}
\multicolumn{1}{|c|}{ Functions } \\
\hline $\begin{array}{l}\text { Growth stimulation, nutrient } \\
\text { availability, uptake capacity, } \\
\text { phytohormones production, } \\
\text { phytopathogens inhibition }\end{array}$ \\
\hline
\end{tabular}

\section{Biotechnological applications}

Biofertilization, phytopathogens biocontrol, phytoremediation of xenobiotics, desert farming, industrial applications (detergents, textiles, paper industry ), desert lands restoration 